\title{
New Distributional Records of Russell's Vipers, Daboia russelii (Shaw and Nodder 1797), in Bangladesh
}

\author{
Naim Khandakar and Kamrun Nahar Jeny
}

Department of Zoology, Jagannath University, Dhaka-1100, Bangladesh (naim.jnu.2014@gmail.com)

$\mathrm{R}^{\mathrm{s}}$ ussell's Viper, Daboia russelii (Fig. 1), is distributed intermittently throughout the Indian Subcontinent, where it occurs in Pakistan, India, Nepal, Bhutan, Bangladesh, and Sri Lanka (Uetz et al. 2019). The species has been assessed as Near Threatened in Bangladesh (Rahman 2015) although an earlier assessment had listed it as Critically Endangered (IUCN Bangladesh 2000). Most publications mentioning Russell's Vipers in Bangladesh are limited to checklists or distributional records. Notable exceptions are studies by Islam (2009) and Hasan et al. (2014), who provided information on ecology, mainly from the literature.

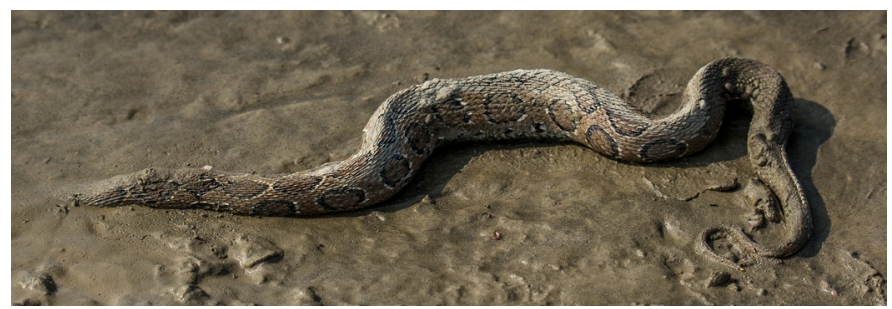

Fig. 1. A Russell's Viper (Daboia russelii) in Rajshahi, Bangladesh. Photograph by Lisun Asib Khan.

These snakes inhabit plains to elevations of $2,100 \mathrm{~m}$ in southern India (Daniel 2002), where it is found in open, grassy or shrubby areas, scrub jungles, forested plantations, rocky hillocks, forest edges, mangroves, and farmlands (Whitaker and Captain 2004). The species is terrestrial and nocturnal, with a diet comprised of rodents, crabs, frogs, lizards, and birds (Das 2002).

Russell's Vipers had been recorded in 17 of 64 districts in Bangladesh (Ahsan and Saeed 2018). Recent reports have added five more districts (Fig. 2). Herein we summarize the past and present distribution of Russell's Vipers in Bangladesh.

We collected distributional data from national and local newspapers, online news portals, wildlife conservation groups, and social media outlets. The previously known distribution was mainly along the Padma and Meghna Rivers and their tributaries. However, one new record in the Tangail District involved snakes in water-filled paddies and another in the Chandpur District was based on a snake rescued from a pond in Koralia. We suggest that snakes might have been carried to new locations by recent floodwaters, as in Fig. 1, but survived and have since reproduced.

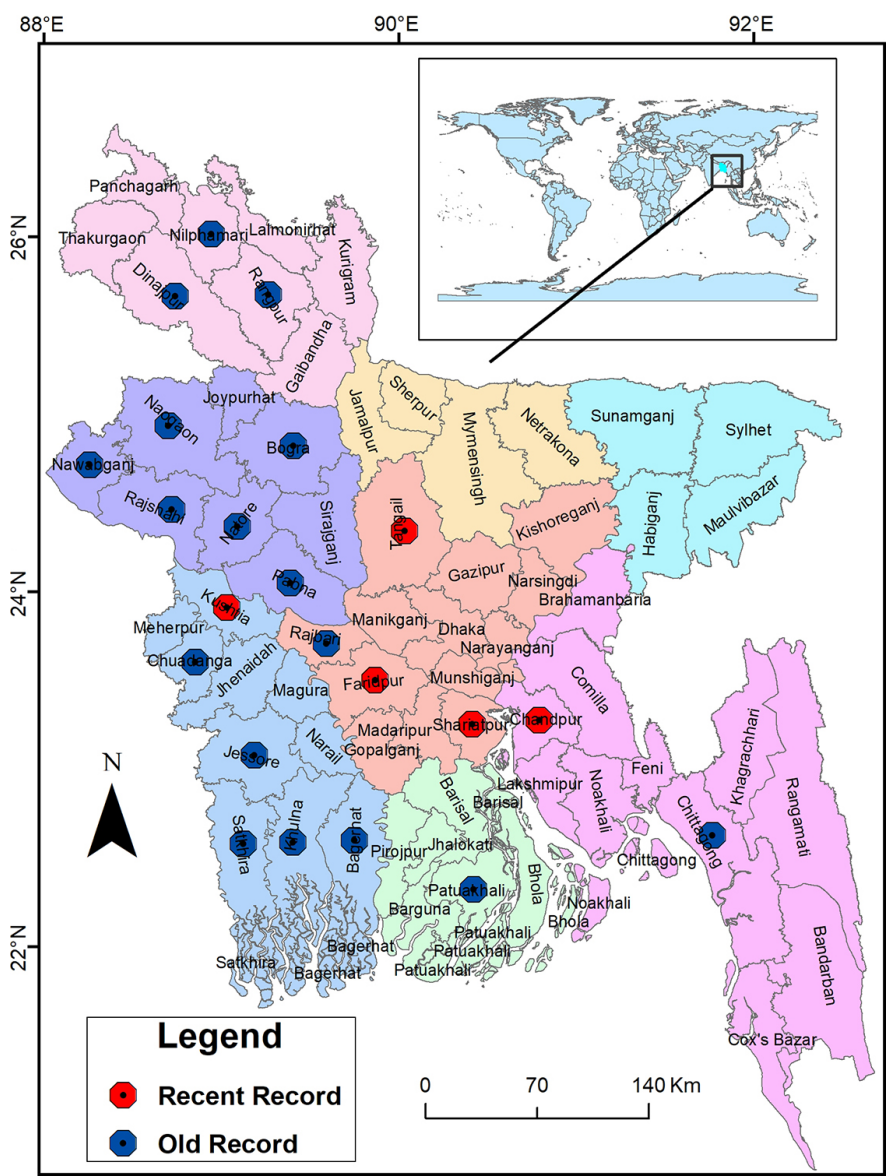

Fig. 2. Distribution of Russell's Viper (Daboia russelii) in Bangladesh. 


\section{Literature Cited}

Ahsan M.F. and M.A. Saeed. 2018. Russell's Viper (Daboia russelii) in Bangladesh: Its boom and threat to human life. Journal of the Asiatic Society of Bangladesh, Science 44: 15-22.

Daniel, J.C. 2002. The Book of Indian Reptiles and Amphibians. Bombay Natural History Society, Oxford University Press, Delhi, India.

Das, I. 2002. A Photographic Guide to Snakes and Other Reptiles of India. New Holland Publishers Ltd., London, UK.

Hasan, M.K., M.M.H. Khan and M.M. Feeroz. 2014. Amphibians and Reptiles of Bangladesh - A Field Guide. Arannayk Foundation, Dhaka, Bangladesh.

Islam, M.A. 2009. Daboia russellii (Shaw and Nodder, 1797), pp. 172-173. In: S.M.H. Kabir, M. Ahmad, A.T.A. Ahmed, A.K.A., Rahman, Z.U. Ahmed,
Z.N.T. Begum, M.A. Hassan, and M. Khondker (eds.), Encyclopedia of Flora and Fauna of Bangladesh, Vol. 25. Amphibians and Reptiles. Asiatic Society of Bangladesh, Dhaka, Bangladesh.

IUCN Bangladesh. 2000. Red Book of Threatened Amphibians and Reptiles of Bangladesh. IUCN-The World Conservation Union, Dhaka, Bangladesh.

Rahman, M.M. 2015. Daboia russelii, p. 103. In: IUCN Bangladesh. Red List of Bangladesh, Volume 4: Reptiles and Amphibians. IUCN, International Union for Conservation of Nature, Bangladesh Country Office, Dhaka, Bangladesh.

Uetz, P., P. Freed, and J. Hošek (eds.). 2019. The Reptile Database. <http://www. reptile-database.org>.

Whitaker, R. and A. Captain. 2004. Snakes of India - The Field Guide. Draco Books, Chennai, India. 